\title{
A TECHNIQUE FOR THE MEASUREMENT OF FLASH FIRE POTENTIAL OF POLYMERIC MATERIALS
}

James E. Brown and John J. Comeford

\author{
Center for Fire Research \\ Institute for Applied Technology \\ National Bureau of Standards \\ Washington, D. C. 20234
}

December 1975

Progress Report

Feb. 1 - Aug. 31, 1974

Sponsored in part by:

Department of Transportation

Federal Aviation Administration

National Aviation Facilities Experimental Center

Atlantic City, N. J. 08405

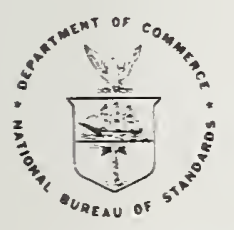

U.S. DEPARTMENT OF COMMERCE, Rogers C.B. Morton, Secrotary James A. Baker, III, Under Secretary

Dr. Betsy Ancker-Johnson, Assistant Secretary for Science and Technology

NATIONAL BUREAU OF STANDARDS, Ernest Ambler, Acting Director 
LIST OF TABLES . . . . . . . . . . . . . . . . . . . . . iv

LIST OF FIGURES • . . . . . . . . . . . . . . . . . . . v v

1. INTRODUCTION . . . . . . . . . . . . . . . . . . . 1

2. EXPERIMENTAL . . . . . . . . . . . . . . . . . . . . . 3

2.1. Materials . . . . . . . . . . . . . 3

2.2. Flash-Fire Cell . . . . . . . . . . . . . . 3

2.3. Pyrolysis Rate Apparatus . . . . . . . . . . . . 3

2.4. Procedure - Flash-Fire Cell Experiments . . . . . . . 4

2.5. Procedure - Evolution Rates of Pyrolysis Products . . 4

3. RESULTS AND DISCUSSION . . . . . . . . . . . . . . . . . 4

3.1. Flash-Fire Cell Experiments . . . . . . . . . . . 4

3.2. Rate of Pyrolyzate Evolution . . . . . . . . . . 7

4. CONCLUSION . . . . . . . . . . . . . . . . . 10

5. ACKNOWLEDGEMENTS . . . . . . . . . . . . . . . . . 11

6. REFERENCES . . . . . . . . . . . . . . . . . 11 
Table 1. Properties of Polyurethane Foams . . . . . . .

Table 2. Results of Pyrolysis with Furnace at $500{ }^{\circ} \mathrm{C}$ and Conditions of the Flash-Fire Cell at the Initial Flash Fire for Sample No. 16.

Table 3. Pyrolysis of Polyurethane No. 16 at Low Temperatures Where Flash Fires Were Not Observed. . . . . . .

Table 4. The Results at the Initial Flash Fire of a Fire Retarded Foam, No. 42 and Unretarded Foams No. 18 and 8 When Pyrolyzed With the Furnace Preset to $500{ }^{\circ} \mathrm{C}$. . . . . . . . . . . . . . 16

Table 5. Minimum Weights of Foams for Production of Flash Fires In the Flash-Fire Cell when the Pyrolysis Furnace was Preset at About $500{ }^{\circ} \mathrm{C}$. . . . . . . . . 
Figure 1. Schematic of Flash-Fire Cell . . . . . . . . . .

Figure 2. Typical Recordings of Sample Temperature and Oxygen Content In Flash-Fire Cell During the

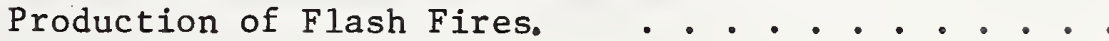

Figure 3. Typical Recording of Sample Temperature and Oxygen Content During Pyrolysis of Sample 16 in the Flash-Fire Cell Without the Production of Flash Fires.

Figure 4. Effect of Temperature and Sample Weight on Production of Flash Fires. . . . . . . . . . .

Figure 5. Recording of the Catalytic Detector Response to Two Major Stages of Combustible Pyrolyzate Evolved from Sample 16 as the Temperature is

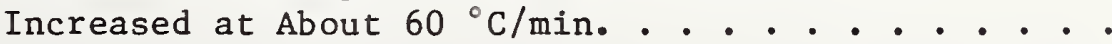

Figure 5a. A Recording Showing the Catalytic Detector Response to The Pyrolyzate Evolved from a Conventional Flexible Foam as the Temperature was Raised at about $60{ }^{\circ} \mathrm{C} / \mathrm{min}$. . . . . . . . . . .

Figure 6. A Typical Recording Showing the Effect of Temperature on the Two Major Stages of Evolution of Total Combustibles from a Polyurethane Shown in Figure 5a.

Figure 7. An Arrhenius Flot of the Results Obtained from the Second Major Stage of the Combustible Pyrolyzate Shown in Figure 6. . . . . . . . . . . . .

Figure 8. A Recording Showing a Reduced First Major Stage as a Result of Removing the "Cracking Coil." . . . . .

Figure 9. A Recording Showing the Total Mass-Flow Rate of Pyrolyzate from the Conventional Polyurethane as the Temperature was Increased at a Rate of $60^{\circ} \mathrm{C} / \mathrm{min}$. 
James E. Brown and John J. Comeford

This report summarizes work for the period February August 1974 on a continuing program to characterize the chemical and physical parameters of importance in a flash fire and to develop laboratory scale methods for measuring the flash fire potential of materials.

Significant modifications have been made to a flash fire cell developed earlier to measure the flash fire potential of materials by characterizing the conditions required to produce an ignitable pyrolyzate-air mixture by thermally degrading a polymer. The furnace temperature, cell geometry and orientation, and sample size are specified. These modifications have resulted in an improved technique, especially in terms of reproducibility, for evaluation of flash fire potential of materials.

Experiments have been conducted on rates of combustible gas formation from flexible polyurethanes to assist in the optimization of the flash-fire cell operating conditions.

In the rate study, two successive major stages of degradation were found for polyurethane as the temperature approached $500^{\circ}$ at a rate of about $60^{\circ} \mathrm{C} / \mathrm{min}$. It was also found that the products of the second stage appear to be responsible for flash fires in the flash-fire cell. A minimum polyurethane weight to enclosure volume ratio greater than $0.2 \mathrm{~g} / 1$ and a sample pyrolysis temperature greater than $380{ }^{\circ} \mathrm{C}$ were required to produce a flash fire in this apparatus.

Key words: Aircraft fires; fire hazard; flash fire; polyurethane; pyrolysis.

\section{INTRODUCTION}

This report describes the research from February, 1974 to August, 1974 on a joint National Bureau of Standards -- Federal Aviation Administration program directed towards ultimately reducing flash fire hazards in inhabited enclosures such as aircraft cabins.

The purpose of this study was to evaluate the parameters which may produce flash fires as a result of thermal degradation of polymeric materials in an enclosed environment. We define a flash fire as a fire (flame front) which propagates through a fuel-air mixture as a result of the energy release from the combustion of that fuel, having required only an ignition source. Since most organic polymers produce combustible 
products during thermal degradation, we set out to determine the conditions under which a flash fire would result from the products of thermal degradation in air of a variety of polyurethane foams, which are recognized to be susceptible to this fire hazard.

A laboratory flash fire cell was developed to permit observation of flash fires resulting from the products of thermal degradation of polymeric material in an enclosed environment.

Observations of flash fires were made using a variety of flexible polyurethane foams. The experimental technique for a given material involved heating the foam in a pyrolysis chamber while allowing the evolved products of pyrolysis to pass into the cell. During the pyrolysis, the temperature of the sample and the oxygen concentration in the cell are recorded. From the change in the oxygen concentration, the volume fraction of the pyrolysis products is inferred. Essentially then, the lower limit of flammability of the pyrolyzate-air mixtures is also recorded when a flash occurs.

Investigations on the products of pyrolysis as a function of temperature were carried out in nitrogen atmospheres by Wooley [1] ${ }^{1}$. He reported that at low temperatures (200 to $300{ }^{\circ} \mathrm{C}$ ) there is a rapid and complete loss of the toluene diisocyanate (TDI) units of the polyurethane as a yellow smoke leaving a residue derived from the comonomer polyol. This suggests that below $500{ }^{\circ} \mathrm{C}$ and perhaps below $750{ }^{\circ} \mathrm{C}$ the initial reaction involves urethane linkage rupture to produce TDI and other aromatic compounds. The familar yellow smoke which contains virtually all of the nitrogen of the polyurethane, was reported to be stable at temperatures up to $750{ }^{\circ} \mathrm{C}$ where other compounds including hydrogen cyanide are formed.

Thermal degradation of polyurethane was also studied by Tilley and co-workers [2] and Napier and Wong [3]. The mechanism of degradation appears to closely follow the mechanism demonstrated by well characterized monomeric urethane compounds [4,5]. Thermal degradation of urethanes generally produced isocyanates, amines, carbon dioxide and alkenes. It was suggested that polyurethanes also produce the nitrogen compounds, carbon dioxide from the urethane groups in the polymer, and unsaturated compounds as well as carbonyl compounds from the polyether-polyol fraction of the copolymer. These latter compounds were identified in an earlier report from our laboratories [6].

We report the technique and results of pyrolyzing several polyurethane foams in the flash-fire cell. We also report an exploratory study of the rate of production of combustible products from polyurethane pyrolysis in nitrogen and the rate of production of volatile combustibles when polyurethane is pyrolyzed in air.

$1_{\text {Numbers }}$ in brackets correspond with the literature references listed at the end of this paper. 


\section{EXPERIMENTAL}

\subsection{Materials}

The polyurethane foams used in this study were all of the flexible polyether type although the molecular weight of the polyether-polyol and method of polymerization differed. The foams, their general formulations and some physical properties are listed in table 1. The formulations and densities were supplied by the manufacturers. The oxygen indices (OI) were kindly supplied by Dr. Robert McCarter [7].

\subsection{Flash-Fire Cell}

A diagram of the flash-fire cell is shown in figure 1. The cell is constructed of a Pyrex cylinder $50 \mathrm{~cm}$ in length and $5 \mathrm{~cm}$ in diameter. The volume of the cell is approximately one liter. Each end of the cylinder has integral " $O$ " ring flanges fitted with neoprene "O" rings and poly(methyl methacrylate) windows which are fastened with springloaded clamps. The cell is equipped with a pyrolysis chamber which is connected to the main cell body by an " 0 " ring flange. The chamber is heated by a regulated electric furnace. The cell also contains an ignition source consisting of a $10 \mathrm{KV}$ AC arc 5 to $10 \mathrm{~mm}$ in length between platinum electrodes and a continuous polarographic oxygen analyzer. The ignition source and detector of the oxygen analyzer are located near the end of the cell farthest from the pyrolysis chamber. During the experiments chromel-alumel thermocouples are used to measure the temperatures of the sample and the furnace.

\subsection{Pyrolysis Rate Apparatus}

The pyrolysis apparatus is designed so that the kinetics of the pyrolysis of polymeric materials may be derived from the evolution of the pyrolysis products. The design and principles of operation of the apparatus are described elsewhere [8]. Essentially, the apparatus consists of a tube furnace allowing arbitrary temperature variations, a quartz pyrolysis tube and a detector to monitor the evolution of pyrolysis products. One of two detectors was used; a combustible gas indicator or a meter measuring the mass flow rate.

The apparatus may be operated with a high-temperature zone near the exit end of the quartz tube. The high-temperature zone is maintained with an electrically heated "cracking coil" which serves to reduce the molecular weight of heavier vapors evolved from the sample and thus prevent condensation. A fine wire (chromel-alumel) thermocouple embedded in the sample measures the temperature of the sample during the pyrolysis. The thermocouple and detector responses are continuously recorded on a two channel recorder. 


\subsection{Procedure - Flash-Fire Cel1 Experiments}

The flash-fire cell was mounted in either a vertical or horizontal position. A weighed sample of the polyurethane foam having a thermocouple (T/C) inserted into it, was placed in the pyrolysis chamber. The cell was assembled as shown in figure 1. The preheated furnace was then brought into position surrounding the pyrolysis chamber so that the foam would quickly reach the pyrolysis temperatures. During the time the sample was being heated, the temperature of the sample and the concentration of oxygen in the cell were continuously recorded on a twochannel recorder.

As the products of pyrolysis evolved from the sample, the 10KV AC arc was turned on for about 2 seconds at chosen intervals, generally every 60 seconds. The sample was heated until a flash occurred or until pyrolysis was complete.

\subsection{Procedure - Evolution Rates of Pyrolysis Products}

In the evolution rate of total combustible gas experiments, a weighed sample of about $10 \mathrm{mg}$ of the polyurethane foam contained in aluminum foil was placed into the quartz tube for insertion into the tube furnace. The air was then flushed from the quartz tube by a flow of nitrogen at a rate of about $15 \mathrm{ml} / \mathrm{min}$ and the "cracking coil" was activated and maintained at a temperature in the range of 550 to $600{ }^{\circ} \mathrm{C}$. The gas evolving from the quartz tube entered the combustible gas detector after mixing with a larger volume of air. The air was pumped through the detector at a rate on the order of $2000 \mathrm{ml} / \mathrm{min}$.

With the activated system in a stable condition, power to the furnace was then turned on and advanced manually at a predetermined rate so as to obtain an increase in the furnace temperature of about $60{ }^{\circ} \mathrm{C} / \mathrm{min}$. The response from the combustible gas indicator which resulted from the products evolving from the sample undergoing pyrolysis was simultaneously recorded with the sample temperature.

In a similar manner, the total pyrolysis products were detected by passing the gases from the quartz pyrolysis tube directly into the mass flow rate meter.

\section{RESULTS AND DISCUSSION}

\subsection{Flash-Fire Ce11 Experiments}

All experiments in the flash-fire apparatus were carried out at atmospheric pressure. As the pyrolysis products evolved into the cell in these experiments, the air was displaced. Hence, before ignition occurs, the decrease in oxygen concentration in the cell is attributed to displacement of the air by the pyrolyzate. 
It is possible that some of the oxygen in the cell may be consumed by oxidation of the polyurethane during the pyrolysis, but the extent of this oxidation is expected to be small since the air surrounding the sample would be rapidly displaced by the products evolving from the sample. No significant gas phase consumption of oxygen is expected in the cell except during the actual burning. Consequently, it is assumed that the oxygen analyzer reading can be related to the volume fraction of the air in the air-pyrolysis product mixture, at least near the ignition source where the flash-fire begins.

Figure 2 shows a typical recording of the oxygen concentration and the temperature of the sample versus time during an experiment in the flash-fire cell. In this experiment flash fires did occur. The flash fires occurred where the two large deflections are seen on the curve showing the concentration of the oxygen.

The oxygen concentration (measured near the ignition source) is expressed as volume percent. The time of heating the sample is in minutes. The temperature is the apparent temperature of the sample during the heating period since thermal gradients and variations in thermal contact between the thermocouple and sample probably exist.

At the onset of a flash fire, a flame front generally propagated from the igniter throughout the cell in the order of 1 second. Ignition of the pyrolyzing sample has not been noted, possibly because of the short duration of the flame in the atmosphere around the sample or because this atmosphere, being nearly oxygen depleted, is near the upper flammability limit. The response of the oxygen analyzer is rapid compared to the duration of the experiment. Thus, the instrument gives a good indication of the diffusion of pyrolysis products to the probe. It also gives an accurate indication of the onset of the flash. The response to the flash fire is reflected by the abrupt change in the curve of oxygen concentration. The magnitude of these deflections appears to be related to the intensity of the flash itself. On the other hand, the deflections probably are not a true representation of the actual varlations in the oxygen concentration during the flash fire since response of the instrument to the heat released and other effects of the flash fire are not presently known.

Listed in table 2 are the results and the conditions at which flash fires were reproduced in the flash-fire cell by pyrolysis of sample No. 16. This sample was used to evaluate the effect of varying the conditions in the flash-fire cell.

The conditions evaluated in these experiments were, (a) orientation of the flash-fire cell, (b) the use of a glass wool filter in the pyrolysis chamber for aerosols and particulates, and (c) the effect of adding air to the pyrolysis product-air mixture. In all cases flash fires were produced regardless of the state or presence of these conditions. In most instances several flash fires were produced during the pryolysis when the sample weight was of the order of $0.8 \mathrm{~g}$. A flash was not produced when the sample pyrolysis temperature was less than $380^{\circ} \mathrm{C}$. We did observe, 
however, some flaming at the electrodes from condensed pyrolysis products. The results of the pyrolysis of the polyurethane foams at the lower temperature are shown in table 3. The temperatures 1isted are the maxima obtained by the foams during the pyrolyses and the times indicate the length of time the foams were pyrolyzed. The percent oxygen listed is the minimum volume fraction of oxygen measured.

In the course of the flash-fire experiments, we observed that the initial pyrolyzate entering the cell was a smoke, yellow to dark brown in appearance [1]. We attempted to filter this product, particulates and possibly aerosol of heavy ofls and tars, from the pyrolyzate. With a glass wool filter placed in the pyrolysis chamber so that the pyrolyzate which entered the cell first passed through the glass wool plug, less condensation of tars and oil was observed on the wall of the flash-fire cell.

The technique derived for the production of flash fires from polyurethane sample 16 was applied to additional foams. A polyurethane foam containing a fire retardant additive and two other foams without fire retardant additives were selected. These foams are identified in table 1 as samples 42, 18, and 8. The results of the pyrolyses of these foams in the flash-fire cell are reported in table 4. All of the runs were made with the flash-fire cell in the vertical position except runs 1 through 3 of sample 42. A glass wool filter was also used in each experiment except runs 2 and 3 of sample 8. In the latter two runs air was added to the cell at rates of 100 and $50 \mathrm{ml} / \mathrm{min}$, respectively. Other than the exceptions mentioned, all experiments reported in table 4 were performed in the same manner. A flash fire was produced in each of the experiments reported in table 4. Although the fire-retarded foam (sample 42) may be more resistant to combustion than any of the other foams used in this study, based on the oxygen indices, flash fires were produced from it by the least amounts of pyrolysis products in the cell.

Having established the minimum pyrolysis temperature for the production of flash fires from the various foams, the sample size was decreased in order to determine the minimum sample weight necessary to produce a flash fire. The foams used in this effort were samples 42, 16 and 8 . The oxygen index of each sample respectively indicates high, moderate and low resistance to combustion. The results for these samples are listed in table 5. The total volume of the flash fire apparatus is about 1.1 liters. For this apparatus, the minimum sample weight appears to be about $0.22 \mathrm{~g}$. This finding suggests that a sample to volume ratio of $0.2 \mathrm{~g} / 1$ can produce sufficient fuel to result in a flash fire when the polyurethane foam is heated to at least $390{ }^{\circ} \mathrm{C}$.

A graphic representation of the flash-fire potential of a flexible polyurethane foam is shown in figure 4 with the results obtained from sample 16. This figure demonstrates the flash-fire potential in terms of sample weight and pyrolysis temperature. The data plotted were taken from tables 2,3 and 4 . 
As far as the effect of the glass-wool filter is concerned, no firm conclusions can be reached. Nevertheless, flash-fire occurrence after a substantial reduction of heavy oils and tars in the flash-fire cell suggested that the flash fire was initiated by the low molecular weight moeities in the pyrolyzate. Moreover, the higher molecular weight moelties evolved during the early stage of the pyrolysis, and at lower sample temperatures, did not alone support flash fires when ignited at or near room temperature. The latter substances appear to be composed chiefly of tars, oils and particulates. Although the lower molecular weight moeities may be primarily responsible for the flash fire, some at least of the heavier components experience combustion during the flash fire. Low molecular weight species of three carbon atoms or less, which are apparently necessary to support a flash fire such as methane, ethane, propylene, and acetone, were shown in a previous report [6] to be present. In table 2, horizontal cell orientation, the experiments to be compared are runs 9 and 14 (filter) with run 15 (no filter); for vertical orientation, runs 6,7 and 8 are to be compared with run 5. Run 2 is unaccountably atypical from several points of view, so we shall exclude it from the discussion. In table 4, runs 2 and 3 of sample 8 , both with vertical orientation, were the only ones in which no filter was used. Inspection of the two tables makes it quite apparent that runs with and without filters show no difference in the percentage of $\mathrm{O}_{2}$ just before the flash. Also, there is no difference in time to flash for the horizontal orientation (runs 9, 14 and 15, table 2). On the other hand, all runs without filter in the vertical orientation have significantly shorter time to flash. The times to flash represent diffusion and mixing phenomena which are not closely controlled. Therefore it is premature to attach much importance to the time data.

We foresee experiments in the flash-fire cell from which a measure of the energy released during flash fires will be obtained. It has been shown [9] that the product. of the lower limit of flammability L expressed as volume fraction and the heat of combustion $\Delta \mathrm{H}_{\mathrm{c}}$ of a large number of organic compounds of diverse classifications approximate a constant, $11 \mathrm{Kcal} / \mathrm{mole}$ of mixture. Using the argument for the energy released by combustion at the lower limit of flammability and considering that the flash-fire cell contains about $4.5 \times 10^{-2}$ moles of gas ( 1.1 liters), we estimate that the energy released from the flash fire is of the order of $0.5 \mathrm{Kcal}$ from the pyrolysis products.

\subsection{Rate of Pyrolyzate Evolution}

To a large degree, the temperatures selected for the furnace of the flash-fire apparatus were predicated on preliminary findings of the combustible-pyrolyzate rate experiments.

Qualitatively we have determined with the pyrolysis rate apparatus [8] that there are two major stages in the total combustible-pyrolyzate evolved during thermal degradation of polyurethane foams. And we have 
also determined that the first major stage contains essentially all of the readily condensable pyrolysis products. These stages of course would be expected when the proposed degradation mechanism of the urethane group is considered $[1,2,3]$.

We show curves of typical combustion-rate experiments in figures 5 (sample 16) and 5A (a conventional foam similar to sample 16, not listed in table 1) for the rate of evolution of the total combustible pyrolyzate and the temperature of the sample, versus time of heating the sample. Although the output voltage of the combustion detector has not been calibrated in terms of energy, the area under the rate curve is proportional to [7] the energy (heat) released by the catalytic combustion of the products from the decomposing polymer. Hence, the magnitude of the response by the detector at any point on the curve is the result of the energy released from combustion of the pyrolyzate at that moment. As it may be seen in figures 5 and $5 \mathrm{~A}$, the first stage of degradation of the foam was not complete before the onset of the second stage though the second stage, occurring at higher temperatures, contains the bulk of the combustible products.

The temperature at which the onset of combustibles is observed and the temperatures for the respective maxima of the first and second stages of degradation are of the same magnitude for the various polyurethane foams. These results indicate that significantly different chemical bonds are broken in the respective stages of pyrolyzate evolution. However, this is not to imply that within the respective stages, the bonds cleaved are necessarily identical chemically but that the cleavage involves bonds of similar energy.

We propose that the stages of the degradation reactions involve different energetics since these stages may be separated by first limiting the pyrolysis temperature of the sample to the temperature of the first stage until the rate of combustible product evolution approaches zero; and then increasing the pyrolysis temperature of the sample through the range for the second stage. This experiment is typified in figure 6 . The shape of the curves in figure 6 suggests that the first stage of disradation consists of more than one product each of which is producid at a different rate. The second stage is expected to be multicomponent but these products seem to be produced at about the same rates. The reason for the variations seen in the two stages could be clarified by rate measurements of the individual components.

Following the example of McCarter [8], we performed an exercise and calculated the rate constants $k$ at several temperatures from about 400 to $475{ }^{\circ} \mathrm{C}$ for the second stage in an experiment as shown in figure 6. A plot was made of the natural logarithm of $k$ versus the reciprocal of the absolute temperature. A plot of these data, figure 7, is linear. This suggests a first order reaction for the second stage where the slope is the ratio of the apparent activation energy to the gas constant, E*/R. An apparent activation energy of $52 \mathrm{Kcal} / \mathrm{mole}$ was calculated. Because this vilue obtained for the activation energy is similar in magnitude to the values found for other materials with oxygen containing functional groups 
$[2,8]$, this excercise serves as a check on the ab1lity of the instrumentation to function as a crude probe for the degradation kinetics. An attempt at estimating the activation energy of the first major stage by the procedure above was not successful. The lack of success may be due to the nature of the various reactions involved in the thermal degradation.

The rate of evolution of combustible pyrolyzate from polyurethane pyrolyzed in air approximates more closely the conditions of the pyrolysis in the flash fire experiments. To achleve these rate 8 tudies, the "cracking coil" was removed from the pyrolysis tube. An example of the record from this study is shown in figure 8. As a result of removing the "cracking coil", a large amount of tars and o1ls condensed in the unheated area of the pyrolysis tube. Therefore, the relative magnitude of the f1rst stage of pyrolyzate evolution is significantly reduced though the onset temperature and the temperature at which the maximum rates occur are essentially the same as in figure 5. This result again suggests that the second stage is composed primarily of low molecular weight combustibles. We have previously shown that flash fires occurred in the flash-fire cell only when the pyrolysis temperature was within the temperature range corresponding to the second stage of the evolution of combustible pyrolyzate.

In the postulated mechanism [1,2] for degradation of polyurethane the products include inert substances such as $\mathrm{CO}_{2}$ as a major component which is produced in the first stage of the degradation process. If a diluent such as $\mathrm{CO}_{2}$ is indeed produced in the early stage of polyurethane degradation, then a substantial increase in the magnitude of the f1rst major stage of pyrolyzate evolution would be observed $1 \mathrm{f}$ the total flow of the pyrolyzate evolved is measured, rather than measuring the merely combustible gases.

A measure of the total mass evolved from the decomposing polyurethane was achieved. To achieve this measurement, the combustion detector was removed from the apparatus and replaced with a mass flow rate meter. With this arrangement, the thermal decomposition products, which were formed in a stream of nitrogen, were swept directly into the mass flow rate meter after passing over the "cracking coil." A graph of the total mass flow rate, temperature, and pyrolysis time is shown in figure 9. The temperatures for the onset of mass flow from the pyrolyzing foam and the maximum rates of evolution are similar to the temperatures of the combustible pyrolyzate experiment for this sample. Since the magnitude of the first stage is quite large and relatively distinct from the second stage, the presence of inert substances are indicated, see also f1gures 5 and $5 \mathrm{~A}$.

The rate of mass flow experiments lend further qualitative support to the idea that polyurethanes thermally degrade in stages, that 1s, the polyurethane first loses the aromatic isocyanate units, and then the polyol undergoes fragmentation.

The two major stages of polyurethane degradation are illustrated with the postulated mechanism [1-5] in the following scheme: 
I. First major stage: Degradation of the urethane group at some temperature below $380^{\circ} \mathrm{C}$.
Polyurethane $\longrightarrow$ Primary aromatic Amine $+\mathrm{CO}_{2}+$ Residue
derived from polyether
$\quad$ Secondary Amines $+\mathrm{CO}_{2}$
$\begin{aligned} & \text { Aromatic disocyanate + Residue of Polyether- } \\ & \text { Polyol }\end{aligned}$

II. Second major stage: Degradation of residues from first stage at temperatures above $380{ }^{\circ} \mathrm{C}$.
Residues of polyether-polyol $\longrightarrow$ Alkanes + alkenes + carbonyl and
compounds + etc.

Derivatives of polyethers

Although flexible foams may contain functional groups other than urethane and other linkages as a result of cross-linking agents and excess diisocyanate for example, this scheme is directed primarily at those groups involved in the polyurethane molecules. Consequently, the above scheme is only intended to illustrate a probable process by which the two major stages of degradations may arise and not the complete process by which all possible products are formed including further reactions of the initial products. However, there are inferences that should be noted; first, two of the three reactions in the first stage yield $\mathrm{CO}_{2}$; and second, this scheme suggests that highly flammable compounds are produced only at elevated temperatures, that is, in the second stage.

The production of $\mathrm{CO}_{2}$ in the early stages of degradation may well account for the large volume. fraction of pyrolysis products in the flashfire cell at the initial flash. Carbon dioxide, being inert, would reduce the flammability of the fuel-air mixture by increasing the heat capacity $[10,11]$ of the gas mixture. In addition, the aromatic compounds evolved in the first stage may also form aerosols and particulates when distilled from the pyrolysis chamber or become a part of the residue. These distilled products condense on the walls and so are not likely to support flash fires near room temperature.

\section{CONCLUSION}

An apparatus has been developed in which flash fires can be reproduced from the pyrolysis products of polyurethane foams. And it seems apparent that the technique developed in this study is applicable to the determination of the flash-fire potential of other polymeric materials.

Flash fires have been reproduced in this apparatus when the sample to volume ratio is not less than $0.2 \mathrm{~g} / 1$ and the pyrolysis temperature of the sample is not less than $380{ }^{\circ} \mathrm{C}$. In these instances, it was also shown that flash fires occur when the oxygen volume fraction is diluted to about $17 \%$ by the pyrolysis products. 
When the temperature of the polyurethane is raised above $390{ }^{\circ} \mathrm{C}$ at $60{ }^{\circ} \mathrm{C} / \mathrm{min}$ for example, the minimum temperature required to achleve a flash fire condition, two major stages of degradation are achieved. We conclude then that the products of the second major stage are primartly responsible for the flame front in the flash fires and that these products include low molecular weight compounds derived from the polyol fraction of the copolymer. The higher molecular weight components in the first major stage, aromatic nitrogen compounds derived from and including the diisocyanate fragments, are not expected to support a flash fire in the flash-fire cell since the temperature in the cell remains near the temperature of the room during the experiment.

\section{ACKNOWLEDGEMENTS}

The investigations described in this report were sponsored in part by the National Aviation Facilities Experimental Center of the Federal Aviation Administration--National Bureau of Standards Work Agreement No. FA 67 NF-AP-21.

We are grateful to Dr. R. J. McCarter for assistance given in the use of the pyrolysis rate apparatus and for making the polyurethane samples available. We also wish to thank Mr. Henry Pierce for obtaining some of the data on the flash-fire cell.

\section{REFERENCES}

[1] Woolley, W. D., Nitrogen-Containing Products from the Thermal Decomposition of Flexible Polyurethane Foams, J. Br. Polym., Vol. 4, 27 (1972).

[2] Tilley, J. N., Nadeau, H. G., Reymore, P. H., Waseciak, P. H. and Sayigh, A. A. R., Thermal Degradative Behavior of Selected Urethane Foams Related to Variations of Constituents, Part II. Chemical Reactions in Urethane Decomposition, J. Cellular Plastics, Vol. 4, 45 (1972).

[3] Napier, D. H. and Wong, T. W., Toxic Products from the Combustion and Pyrolysis of Polyurethane Foams, J. Br. Polym., Vol. 4, 45 (1972).

[4] Dyer, E. and Wright, G. C., Thermal Degradation of Alkyl N-Pheylcarbamates, J. Am. Chem. Soc., Vol. 31, 2138 (1959).

[5] Saunders, J. H., Thermal Degradation and Flammability of Urethane Polymers, Rubber Chem. Tech., Vol. 32, 337 (1959). 


\section{REFERENCES, cont'd}

[6] Paabo, M. and Comeford, J. J., A Study of the Decomposition Products of Polyurethane Foam Related to Aircraft Cabin Flash Fires, Nat. Bur. Stand. (U.S.) Report No. FAA-RD-73-46 (1973).

[7] McCarter, R. J., to be published.

[8] McCarter, R. J., A New Technique for Thermal Analysis of VaporProducing Reactions, J. Appl. Poly. Sc., Vol. 17, 1833 (1973).

[9] Kuchta, J. M., Fire and Explosion Manual for Alrcraft Accldent Investigators, Technical Report No. 4193, Bureau of M1nes, Pittsburgh, Pa. (1973).

[10] Huggett, C., Combustion Process in the Aerospace Environment, Aerospace Med., Vol. 40, 1176 (1969).

[11] Huggett, C., Habitable Atmospheres Which Do Not Support Combustion, Combustion and Flame, Vol. 30, 140 (1973). 


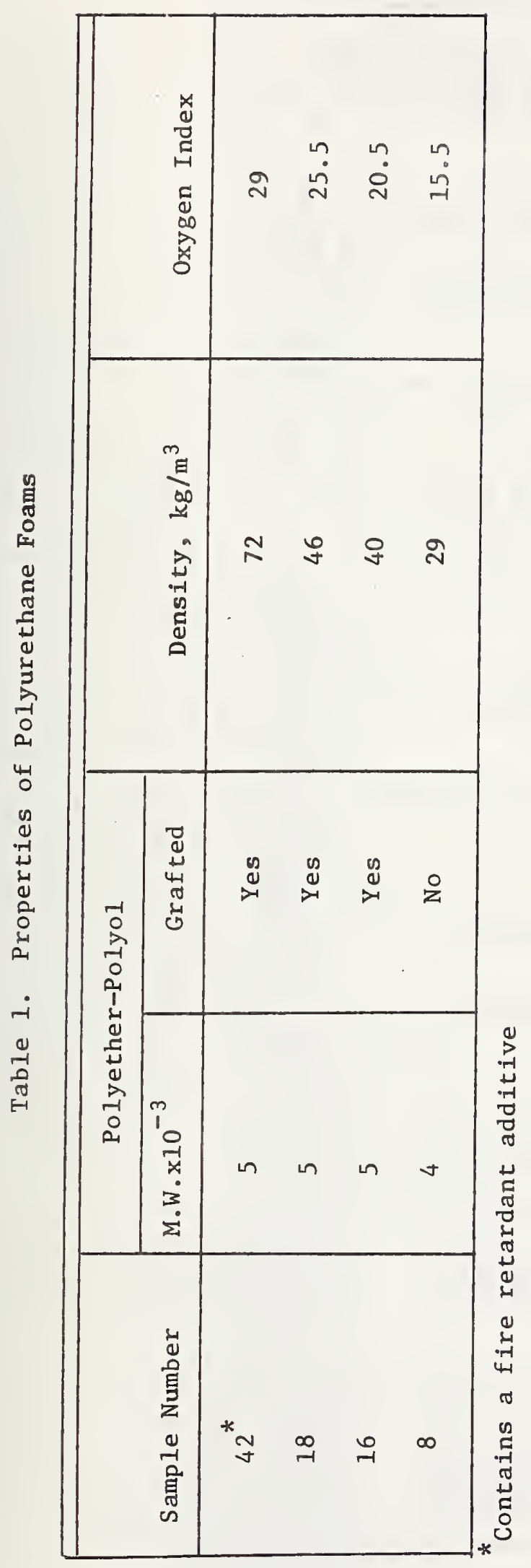




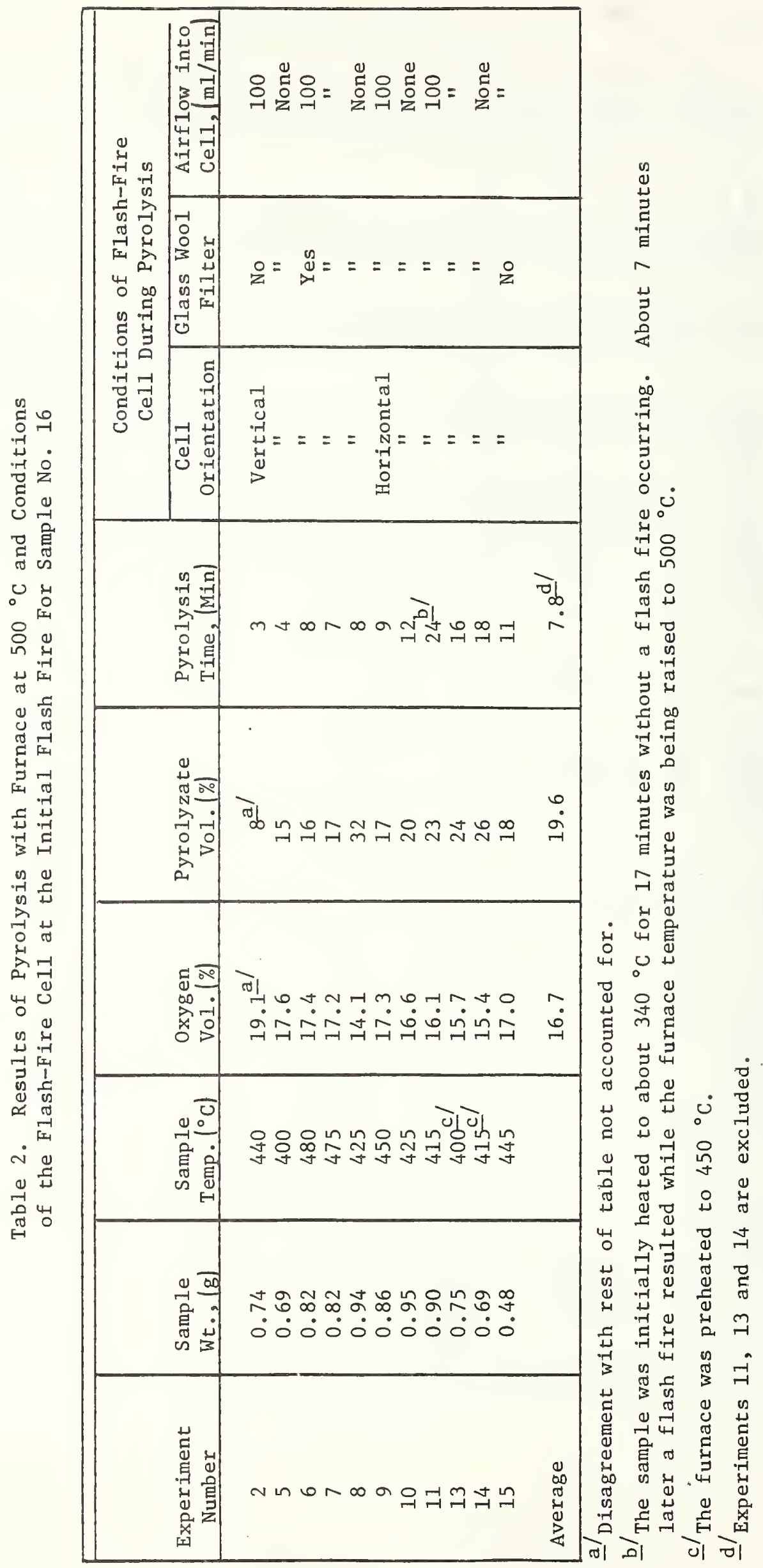




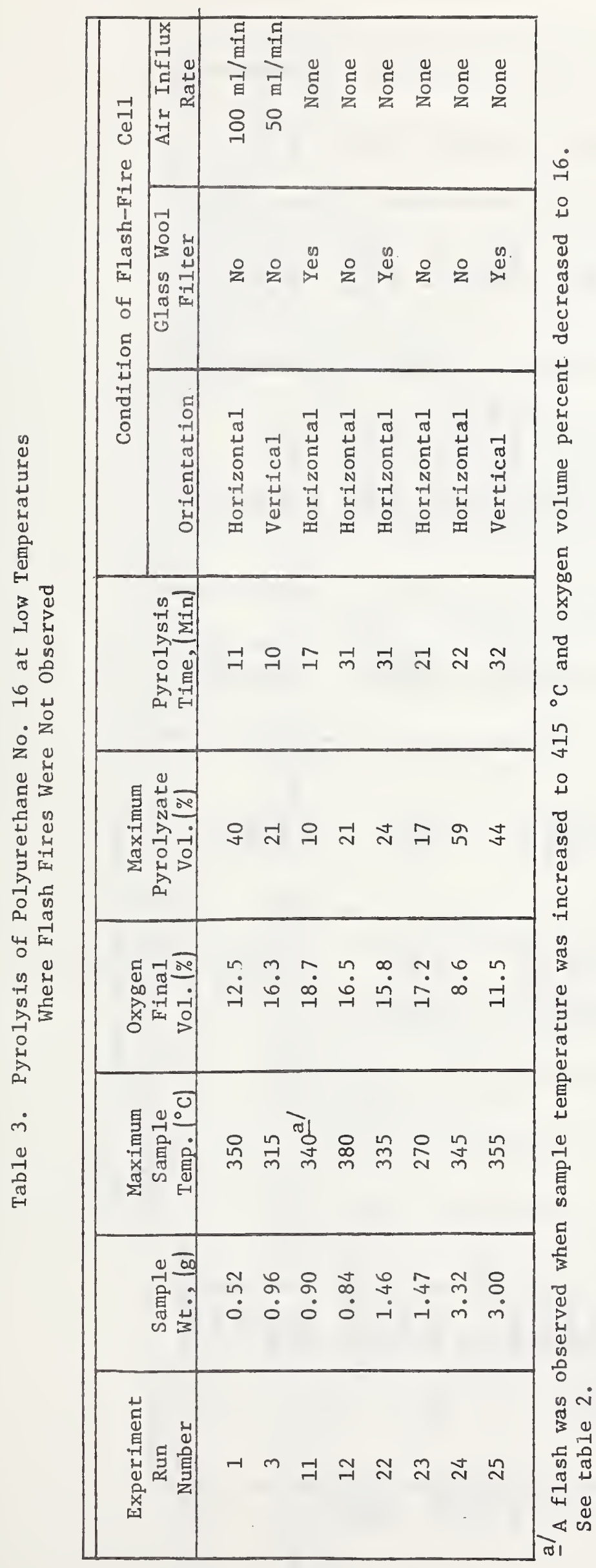




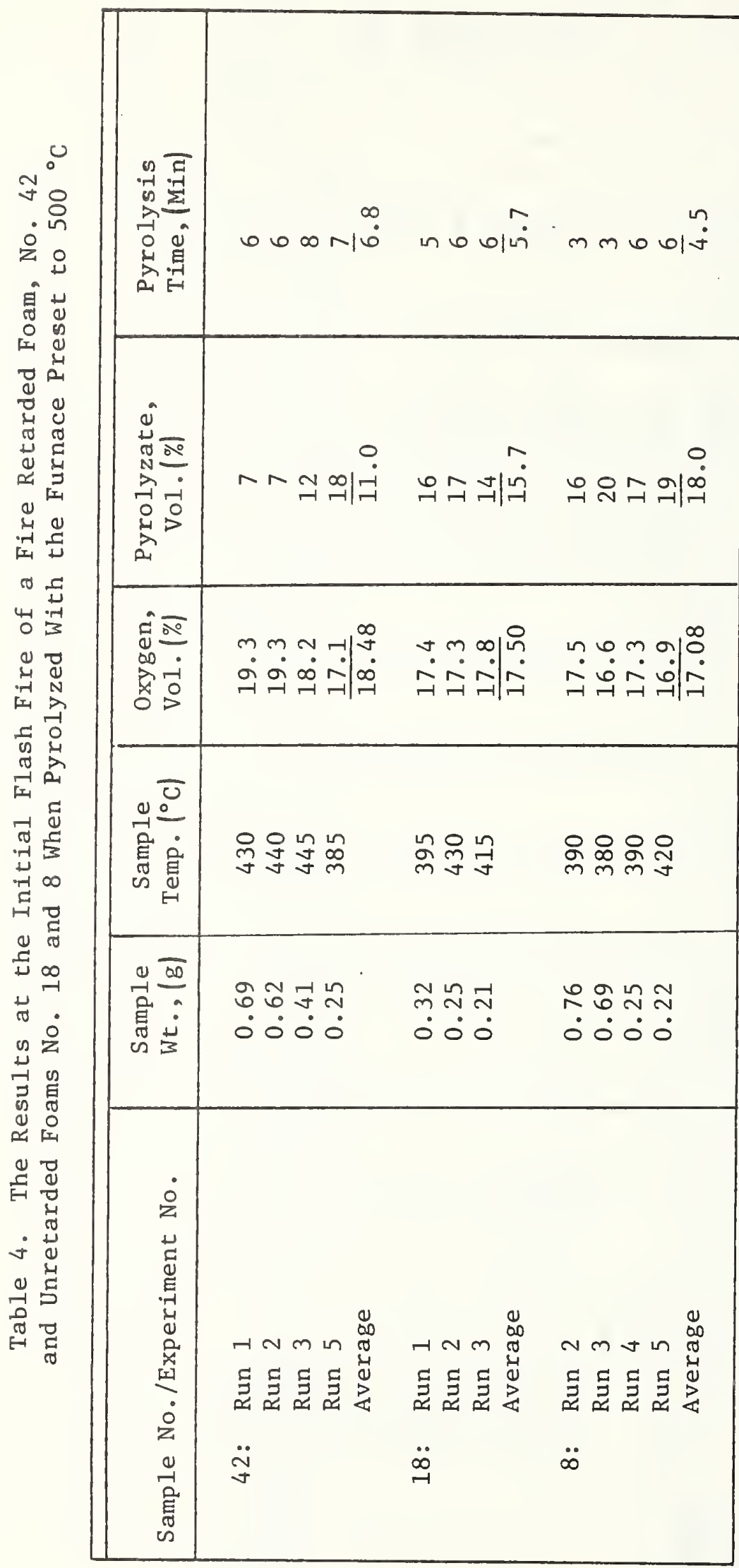




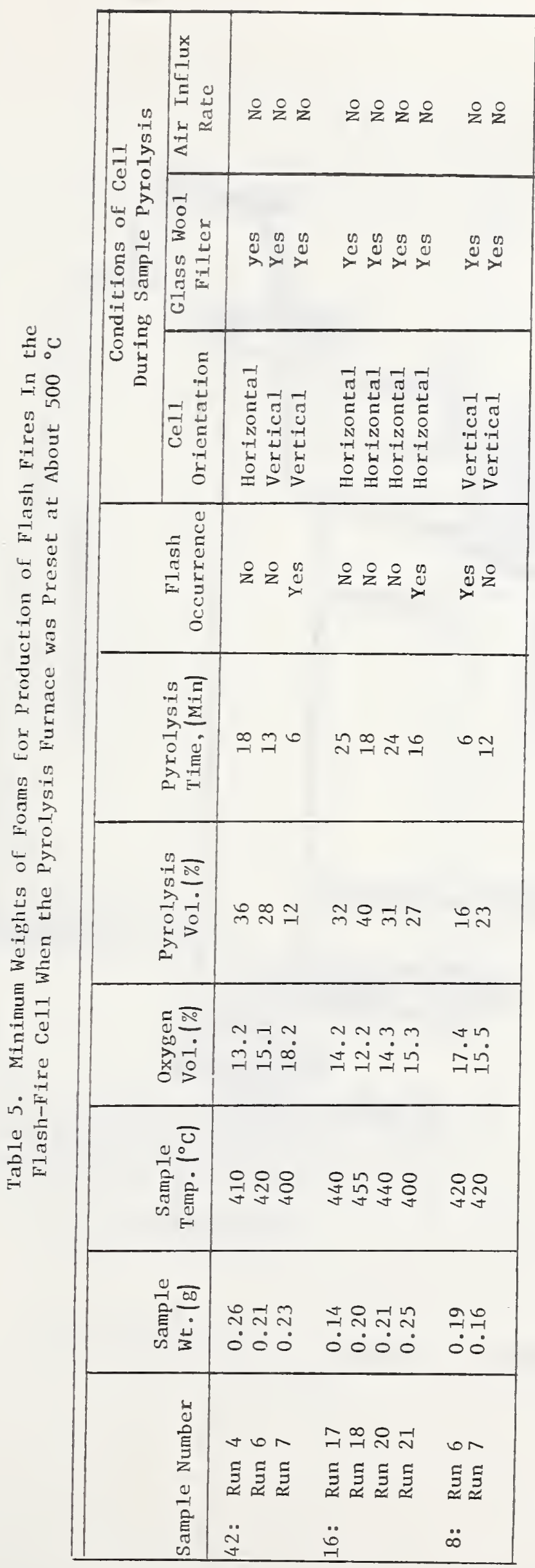




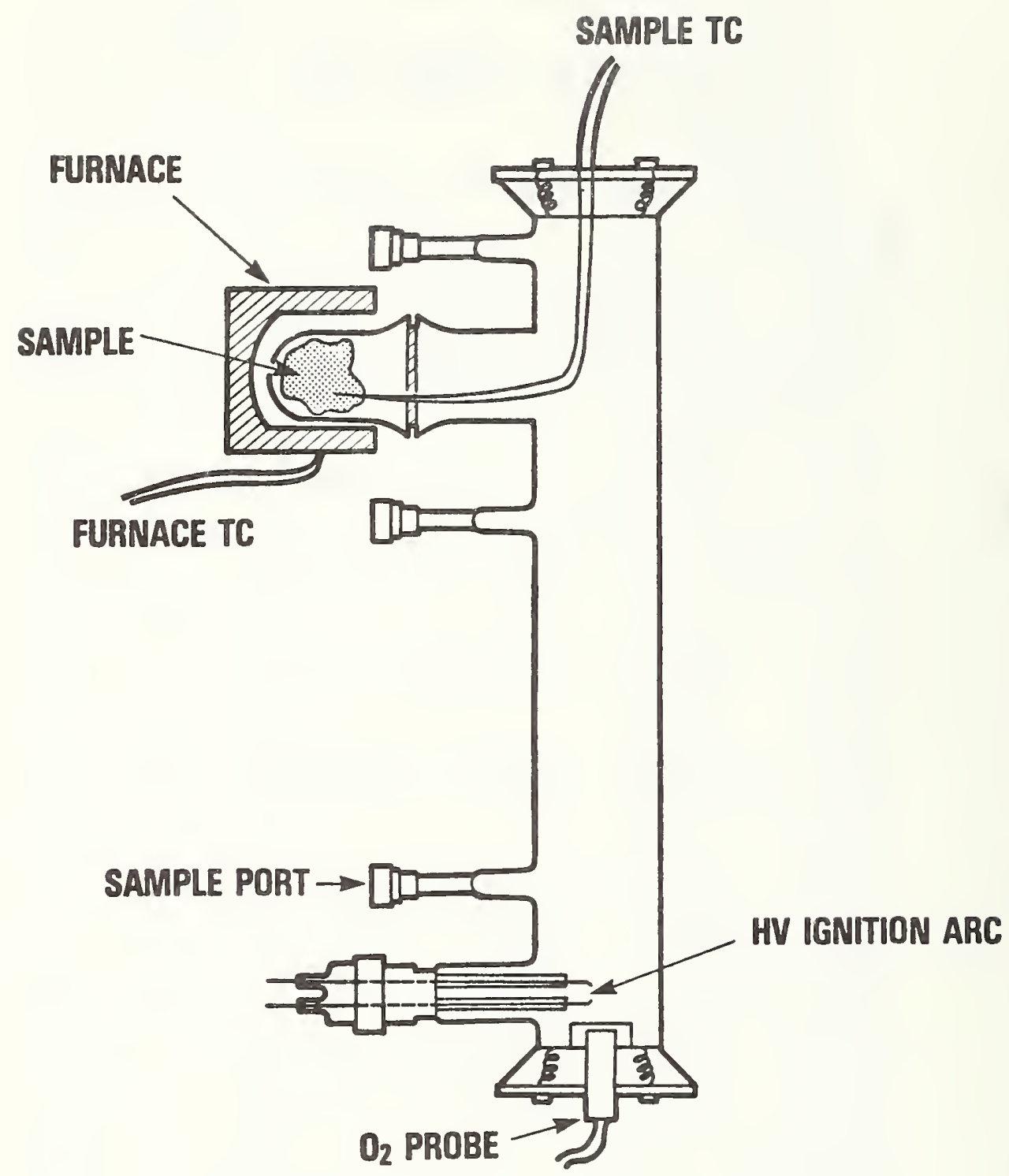

Figure 1. Schematic of Flash-Fire Cell 


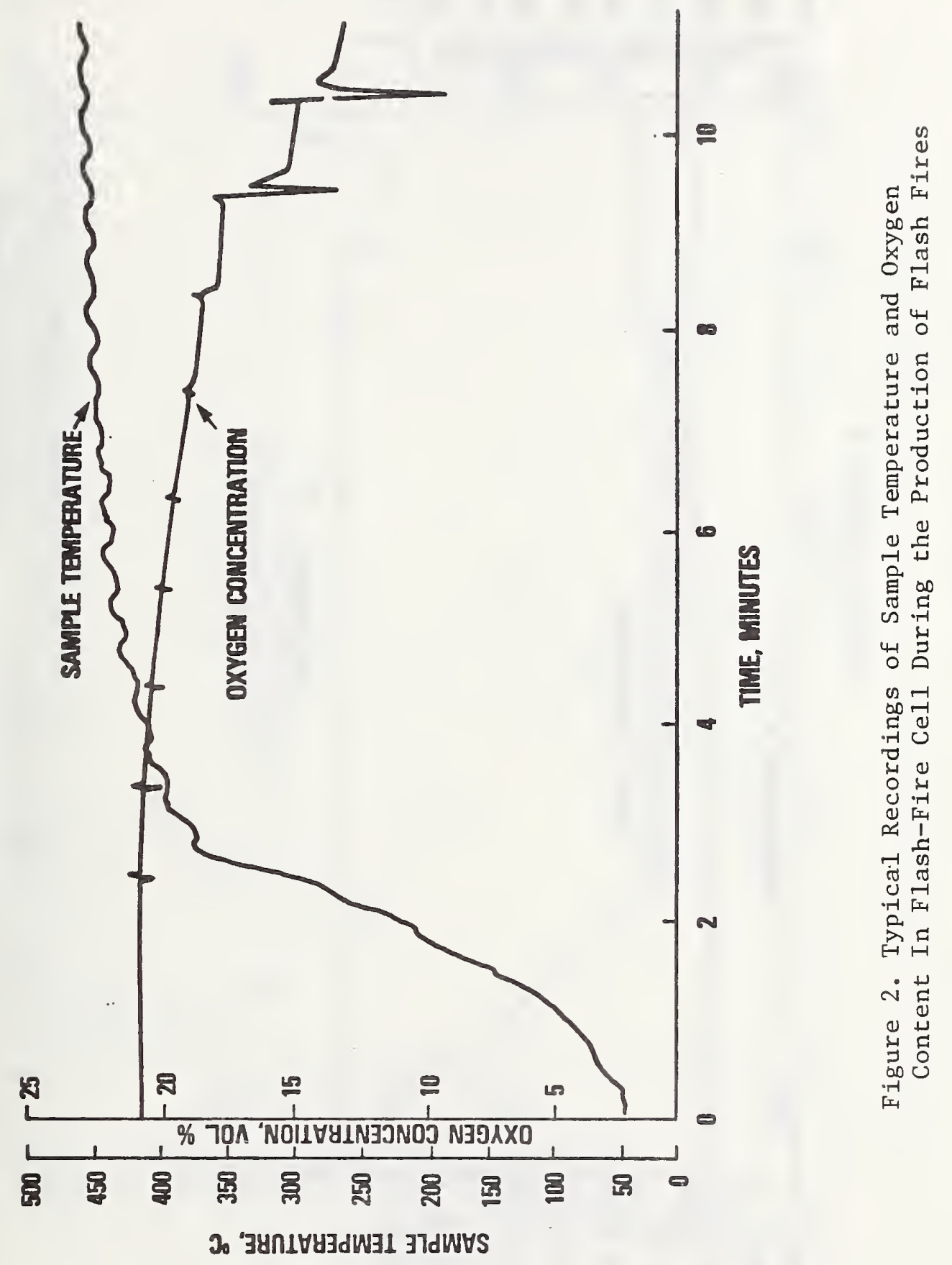


SAMPLE TEMPERATURE, 'C

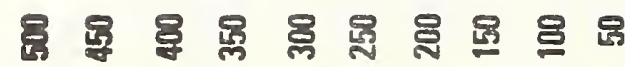
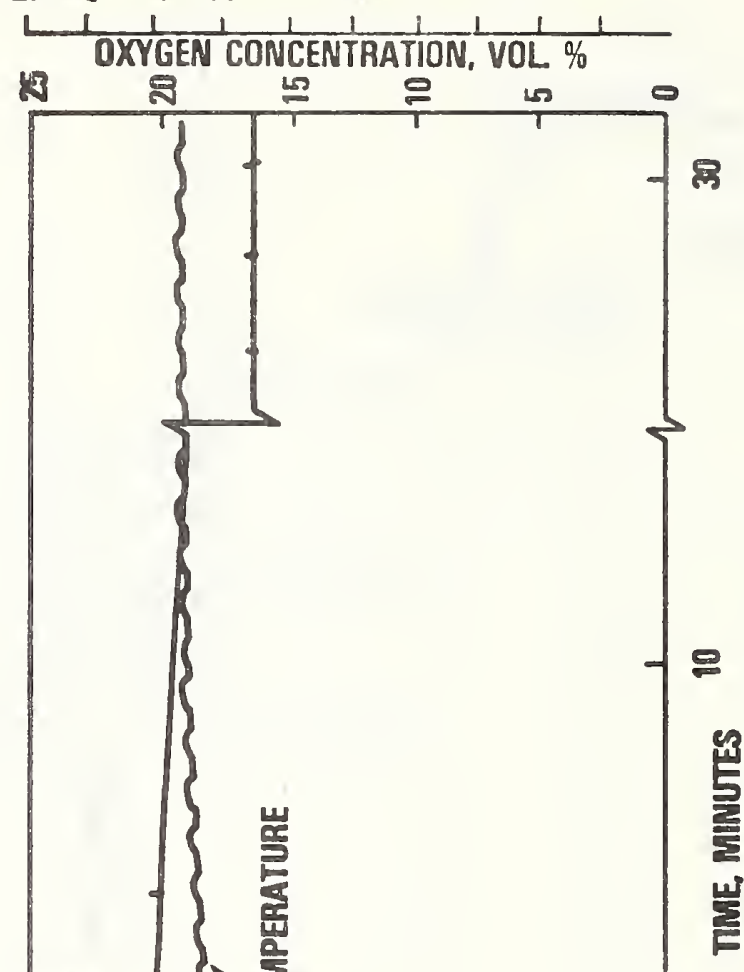

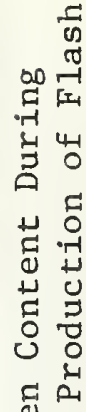

$\infty$

突

물

ขึ

$\stackrel{\leftrightarrow}{3}$

गै न

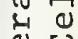

定

E.

( )

का

完苗

is

㟧 站

胥

ㄴ.

군

(1)

\&

$\simeq$

글

บ ल

究出

象

a

$\dot{n} 2$

० \%

范 कo कि

4

ลั

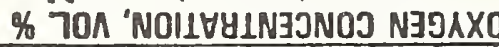

r.

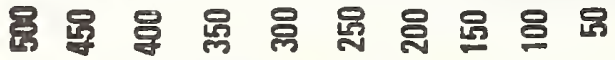

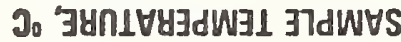




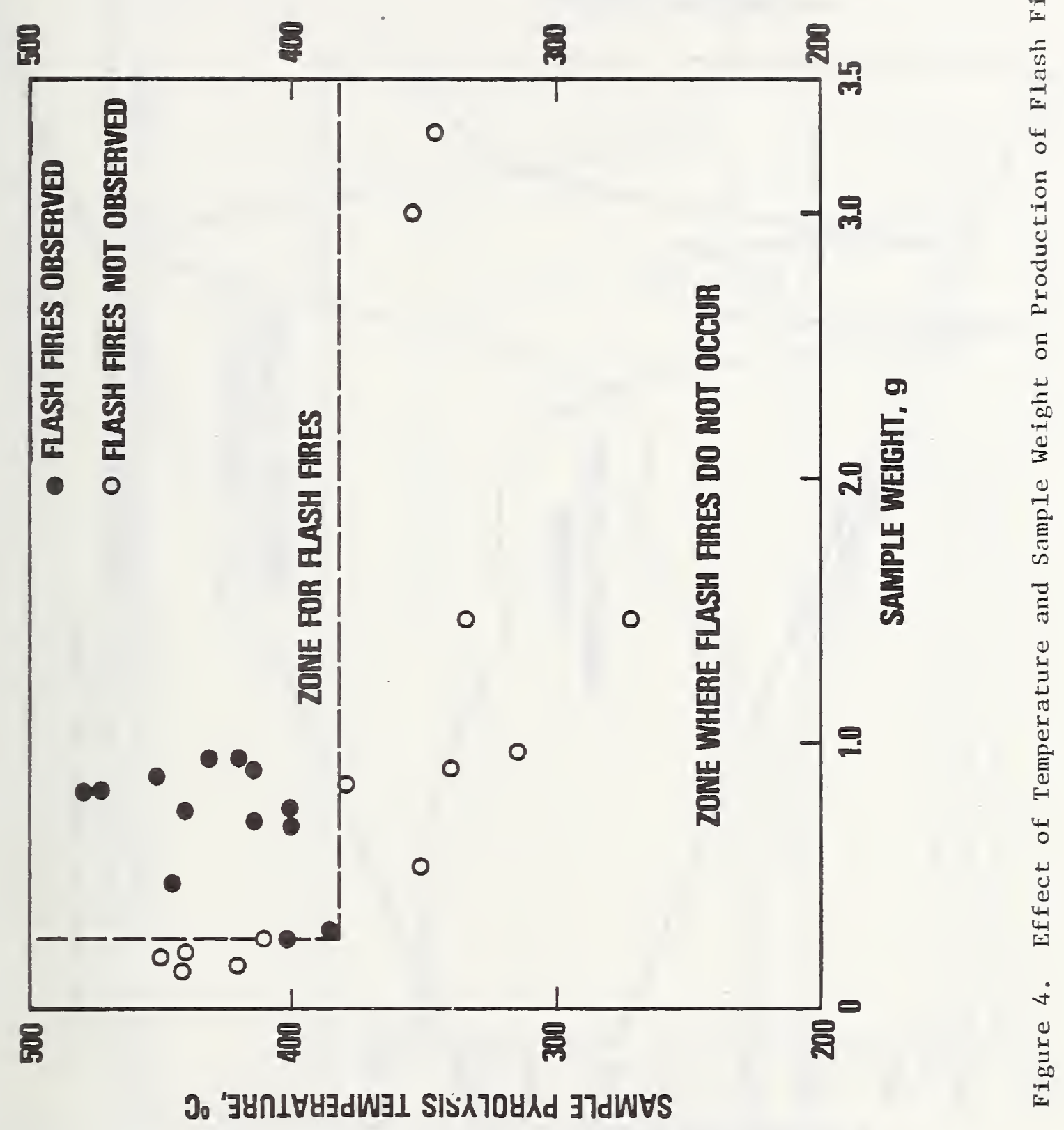



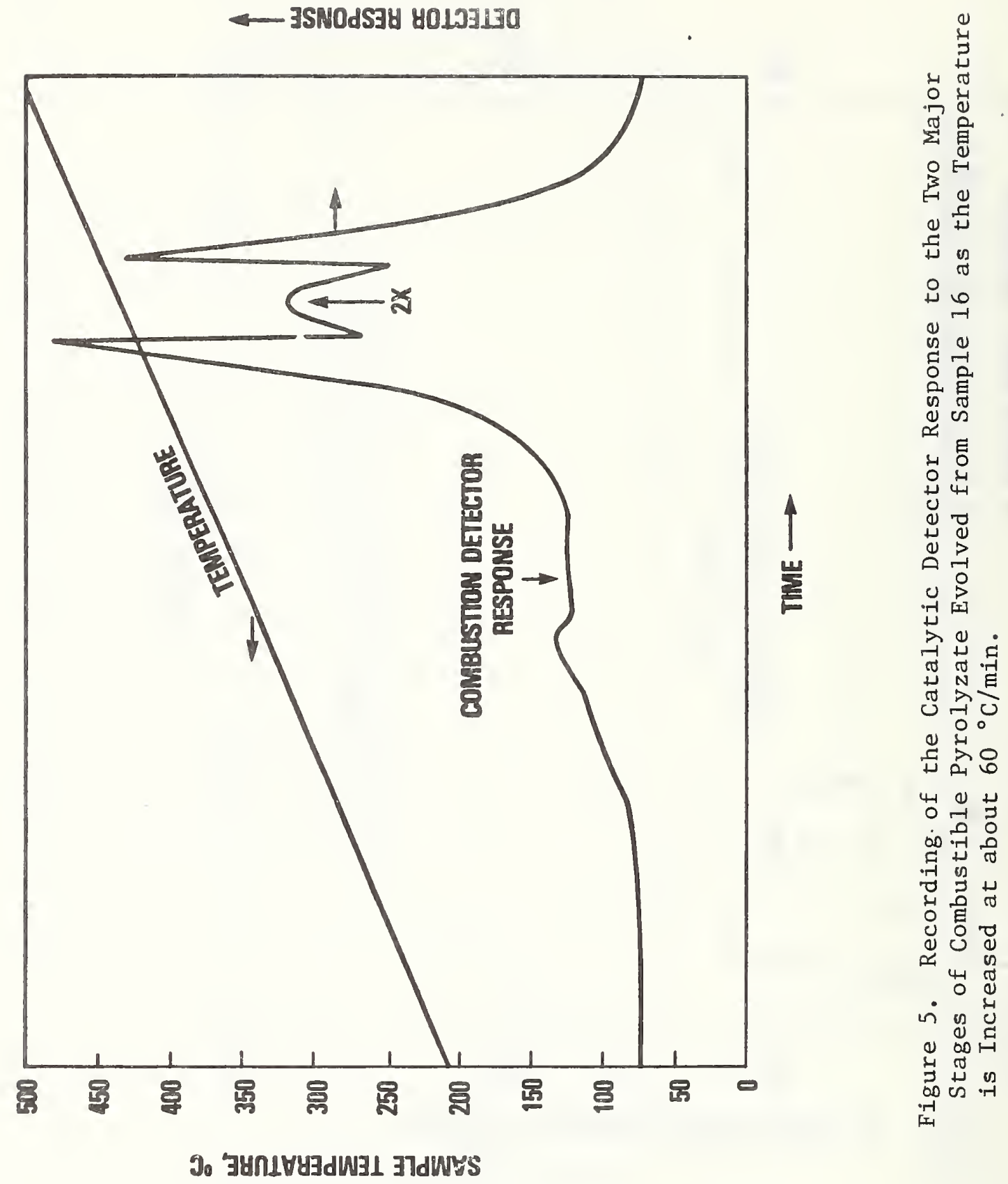


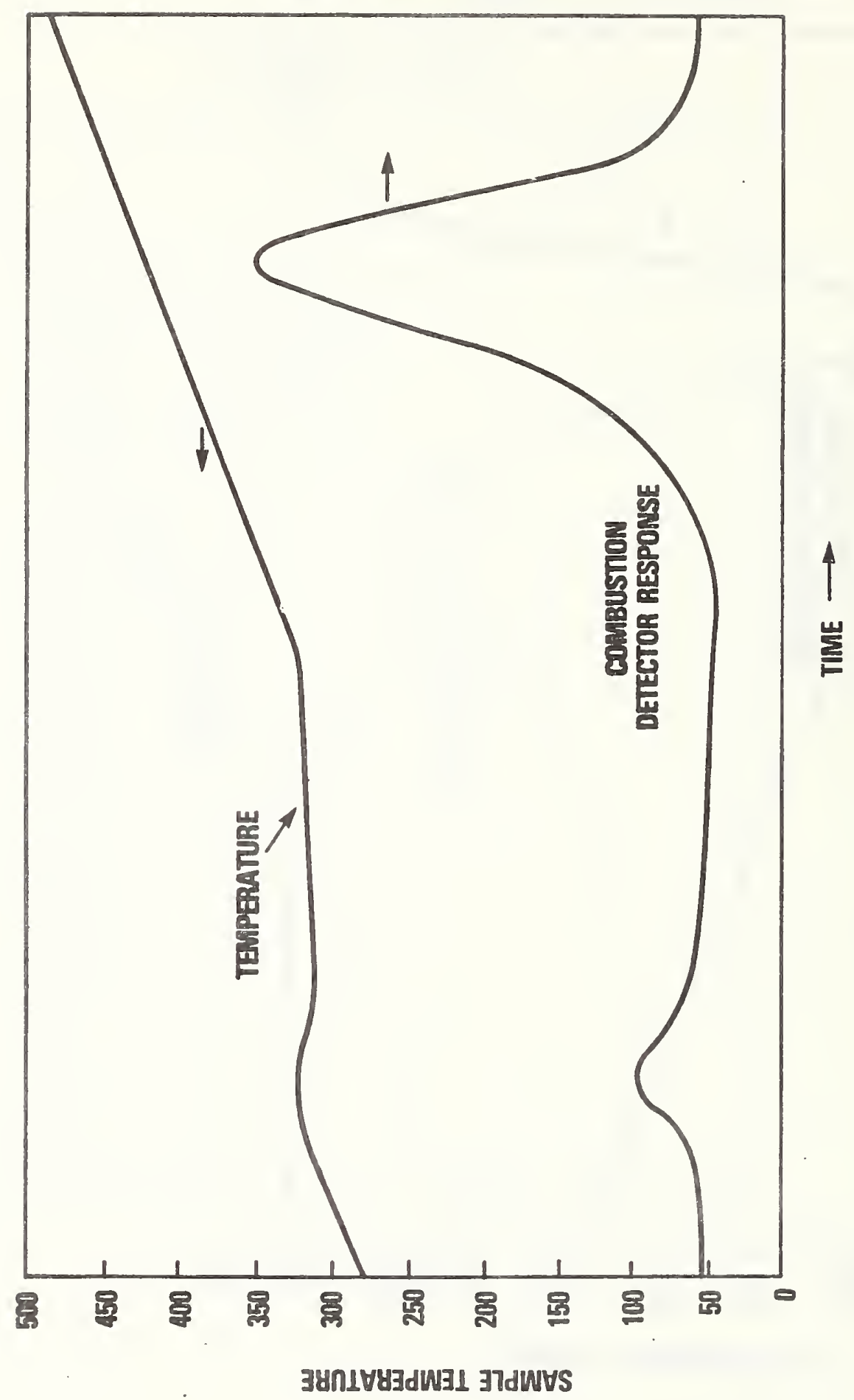

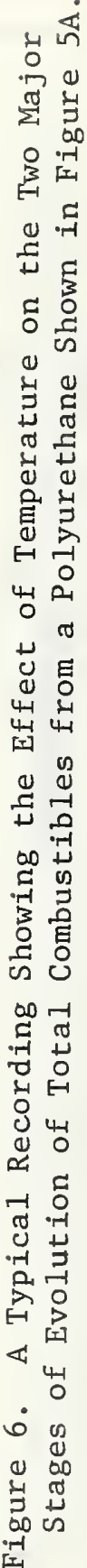

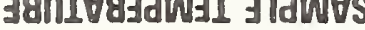




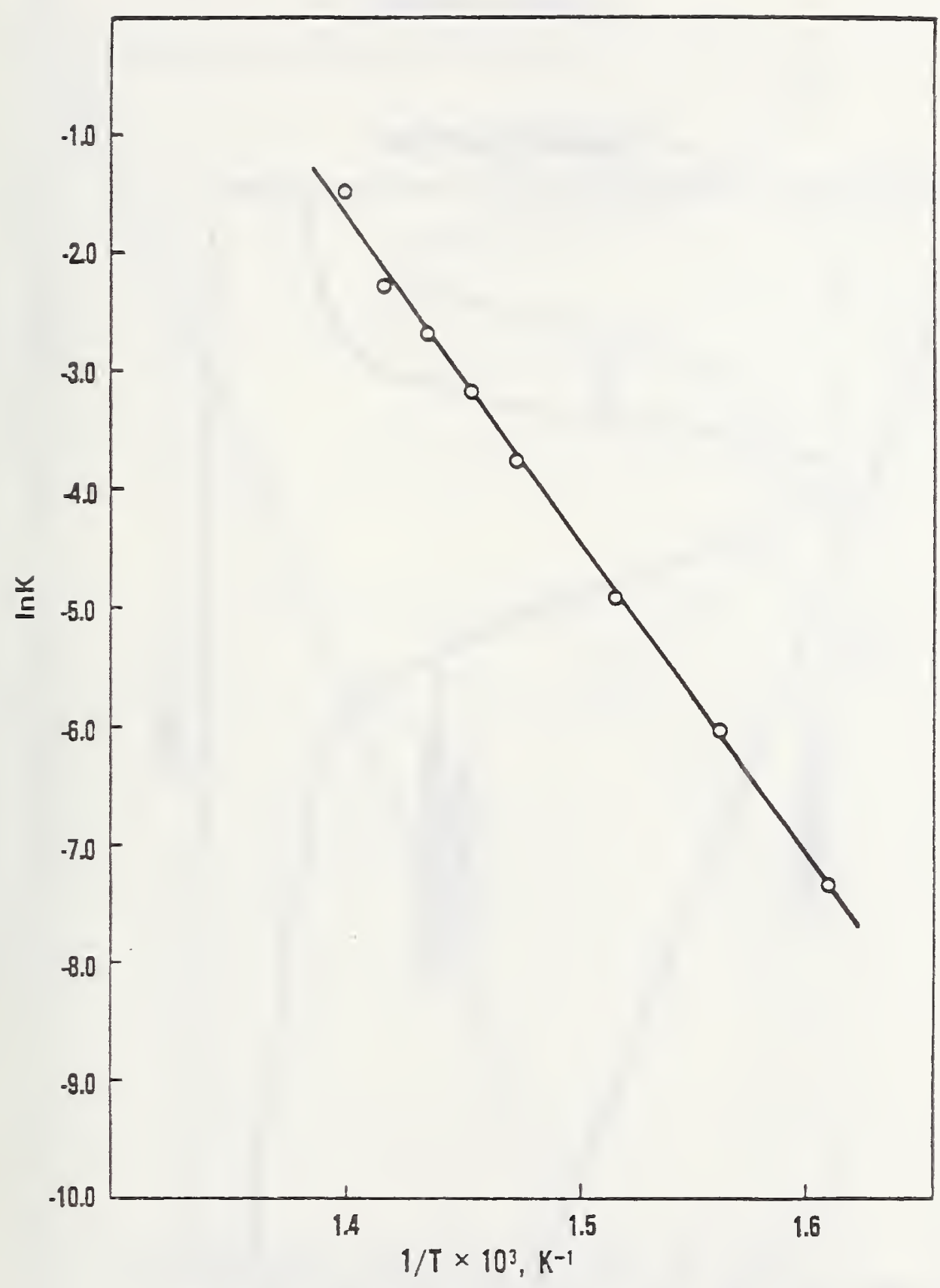

Figure 7. An Arrhenius Plot of the Results Obtained from the Second Major Stage of the Combustible Pyrolyzate Shown in Figure 6 . 


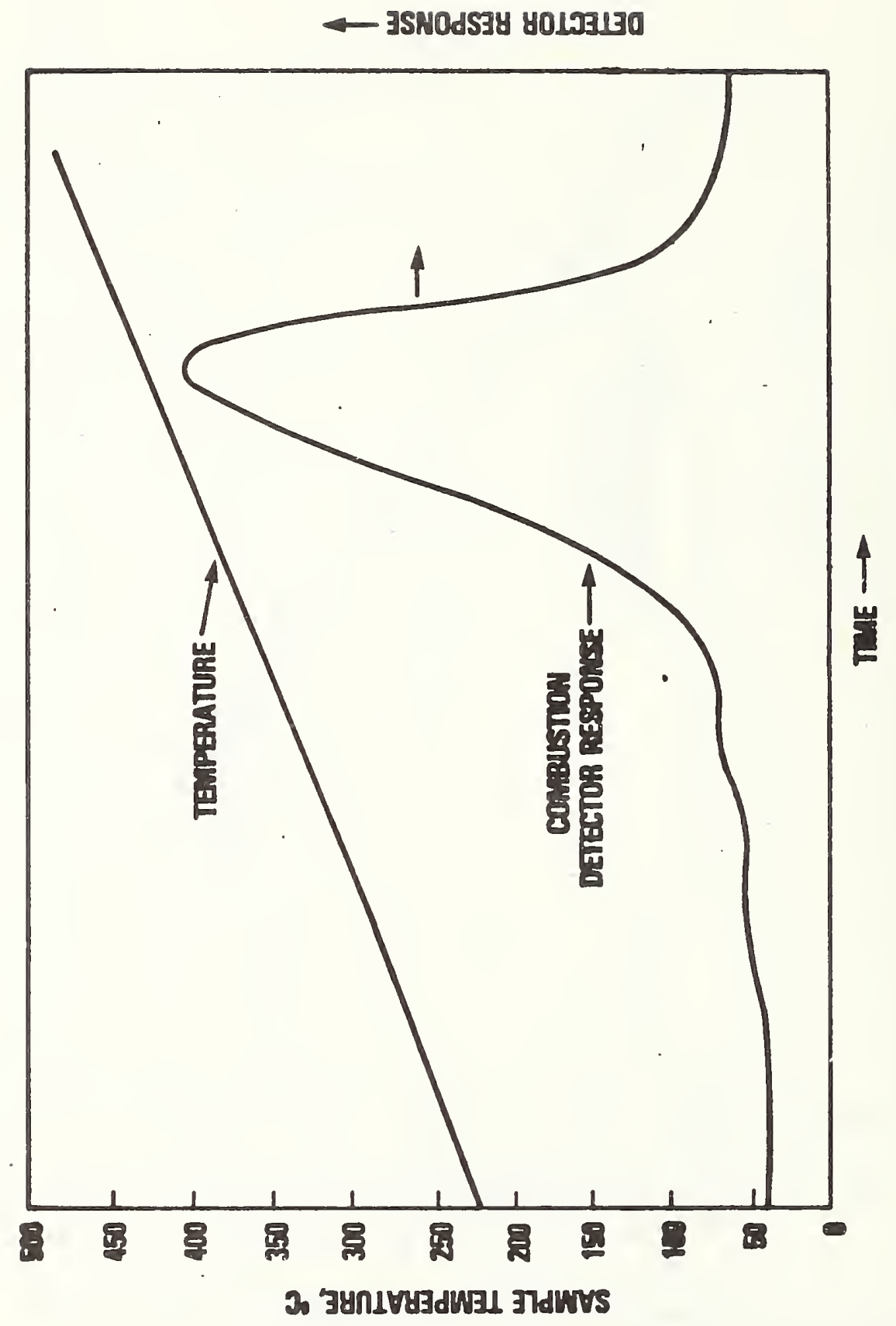

$=$
-1
70
0
00
.
$\frac{7}{0}$
0
0
0
$=$

点

告

4

章

$\pi$

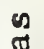

0

尔

急

뭉

$\pi^{\pi}$

煦

:

D

ป్త

$\pi$

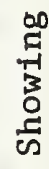

㟔

4

$\infty$

幽 


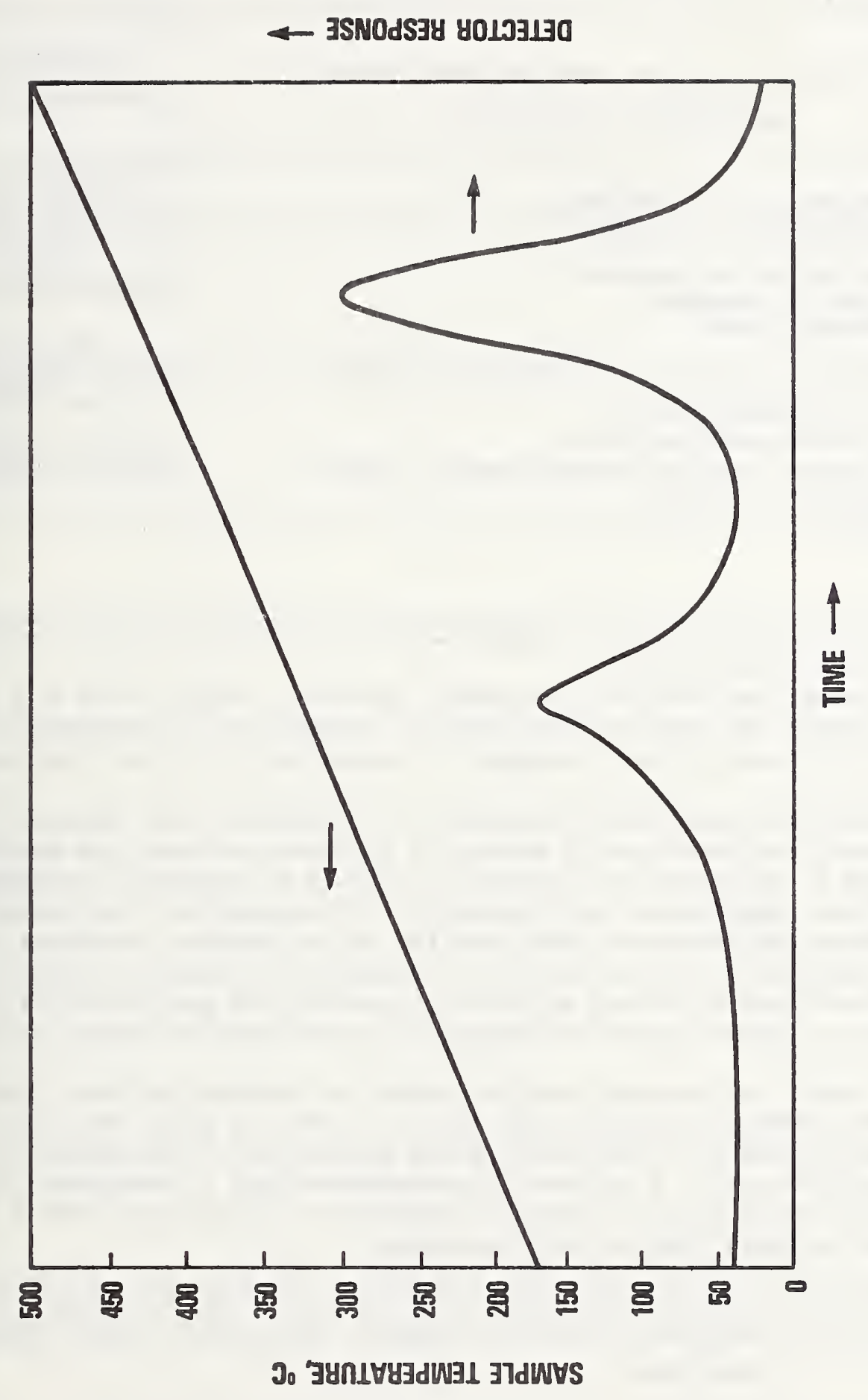

当

뉸

봉

出 0

崩苋

N

त्र

유

रे

प4

()

更

30

厌 3

is o

of

$\sum^{\pi}$

-1

皆葛

E

过

胥为

弪 胥

的造

00

击

प्र त्र

บै

\& -1

4 ठ

वं

\&

齐

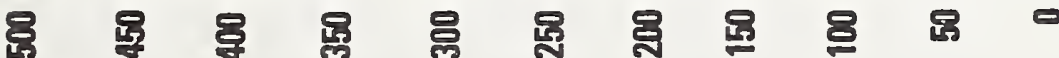


NBS-114A (REV. 7.73)

\begin{tabular}{|c|c|c|}
\hline $\begin{array}{c}\text { U.S. DEPT. OF COMM. } \\
\text { BIBLIOGRAPHIC DATA } \\
\text { SHEET }\end{array}$ & $\begin{array}{c}\text { 1. PUBLICATION OR REPORT NO. } \\
\text { NBSIR 75-757 }\end{array}$ & $\begin{array}{c}\text { 2. Gov't Accession } \\
\text { No. }\end{array}$ \\
\hline
\end{tabular}

4. TITLE AND SUBTITLE

A Technique for the Measurement of Flash Fire Potential of Polymeric Materials

5. Publication Date

\title{
December 1975
}

6. Performing Organization Code

7. AUTHOR(S)

James E. Brown and J. J. Comeford

8. Performing Organ. Report No. NBSIR 75-757

9. PERFORMING ORGANIZATION NAME AND ADDRESS

\author{
NATIONAL BUREAU OF STANDARDS \\ DEPARTMENT OF COMMERCE \\ WASHINGTON, D.C. 20234
}

12. Sponsoring Organization Name and Complete Address (Street, City, State, ZIP)

Department of Transportation

Gederal Aviation Administration

National Aviation Facilities Experimental Center

Atlantic City, N.J. 08405

15. SUPPLEMENTARY NOTES

16. ABSTRACT (A 200-word or less factual summary of most significant information. If document includes a significant bibliography or literature survey, mention it here.)

This report summarizes work for the period February - August 1974 on a continuing program to characterize the chemiral and physical parameters of importance in a flash fire and to develop laboratory scale methods for measuring the flash fire potential of materials.

Significant modifications have been made to a flash-fire cell developej earlier to measure the flash fire potential of materials by characterizing the condition required to produce an ignitable pyrolyzate-air mixture by thermally degrading a polymer. The furnace temperature, cell geometry and orientation, and sample size are specified. These modifications have resulted in an improved technique, especially in terms of reproducibility, for evaluation of flash fire potential of materials.

Experiments have been conducted on rates of combustible gas formation from flexible polyurethanes to assist in the optimization of the flash-fire cell operating conditions.

In the rate study, two successive major stages of degradation were found for polyurethane as the temperature approached $500^{\circ}$ at a rate of about $60{ }^{\circ} \mathrm{C} / \mathrm{min}$. It was also found that the products of the second stage appear to be responsible for flash fires in the flash-fire cell. A minimum polyurethane weight to enclosure volume ratio greater than $0.2 \mathrm{~g} / 1$ and a sample pyrolysis temperature greater than $380{ }^{\circ} \mathrm{C}$ were required to produce a flash fire in this apparatus.

17. KEY WORDS (six to twelve entries; alphabetical order; capitalize only the first letter of the first key word unless a proper name; separated by semicolons) Aircraft fires; fire hazard; flash fire; polyurethane; pyrolysis.

18. AVAILABILITY Tritunlimited

For Official Distribution. Do Not Release to NTIS

Order From Sup. of Doc., U.S. Government Printing Office

Washington, D.C. 20402, SD Cat. No.C13

[I] Order From National Technical Informat:

Springficld, Virginia 22151

\begin{tabular}{|c|c|}
\hline $\begin{array}{c}\text { i9. SECUPITY CLASS } \\
\text { (THIS REPUR T) }\end{array}$ & 21. NO. OF PAGES \\
UNCLASSIFIED & 32 \\
\hline $\begin{array}{c}\text { 20. SECURITY CLASS } \\
\text { (THIS PAGE) }\end{array}$ & 22. Price \\
UNCLASSIFIED & $\$ .75$ \\
\hline
\end{tabular}



